4. Яргина 3.Н., Косицкий Я.В. Основы теории градостроительства: Учебник для вузов. М.: Стройиздат, 1986. 326с.

5. Михайлов С.М. Дизайн Современного города: Комплексная организация предметнопространственной среды (теоретико-методологическая концепция): дис. ... д-ра искусствоведения: 17.00.06 / Всерос. науч.-исслед. ин-т техн. эстетики. М., 2011. 362с.

6. Дубинський В. П. Скоробогатько О.В. Ергономічний аспект формування архітектурного партеру сучасного міста. Науковий вісник будівниитва. 2018. Том 92(№2). С. 69-73.

7. Беляева Е. Л. Архитектурно-пространственная среда города как объект зрительного восприятия. М.: Стройиздат, 1977. 127с.

8. Мироненко В.П., Сопов Д.В. Когнитивный диссонанс в восприятии архитектурного пространства. Науковий вісник будівництва. 2017. Том 87(№1). С. 39-42.

9. Глазычев В. Л. Город без границ. М.: Territoriia budushchego, 2011. 400c.
Дубинский В.П., Скоробогатько А.В. ПРИНЦИПЫ ФОРМИРОВАНИЯ АРХИТЕКТУРНОГО ПАРТЕРА СОВРЕМЕННОГО ГОРОДА.

В данной статье были проанализированы условия формирования архитектурного партера, выявлено три аспекта при которых происходит организация архитектурного партера, и были выявлены принципы формирования архитектурного партера современного города.

Ключевые слова: архитектурный партер, зона ближнего восприятия в архитектуре, градостроительный партер, городской партер, принципы формирования архитектурного партера современного города.

\footnotetext{
Dubinskiy V.P., Skorobohatko O.V. THE PRINCIPLES OF FORMATION OF ARCHITECTURAL PARTEREE OF MODERN CITY. In this article the conditions for the formation of the architectural parterre were analyzed, three aspects were revealed during which the organization of the architectural parter was organized, and the principles of the architectural part of the modern city were identified.

Keywords: architectural parterre, a zone of the nearest perception in architecture, a town-planning parterre, a city parterre, principles of formation of architectural parterre.
}

DOI: $10.29295 / 2311-7257-2019-96-2-8-14$

УДК $72.03+725.2$

Smolenska S.A., Borysenko A.S.

Kharkiv National University of Civil Engineering and Architecture

(Sumska street, 40, Kharkiv,61002,Ukraine email: smollana@gmail.com, argeciy@gmail.com; orcid.org/0000-0002-4953-9563, orcid.org/0000-0001-5629-2768)

\title{
THE SHIFT OF PERSPECTIVE IN SHOPPING CENTER DESIGN IN 2000-2010S
}

The article is dedicated to studying modern world trends in shopping center design. An analysis of contemporary theoretical publications on the subject is conducted in order to accomplish that goal, accompanied by the most illustrative examples showcasing changes in functioning, composition and design of shopping centers in 2000-2010s. Consequently, assumptions according to the causes of perceived changes in design paradigm are made, and its consequences for the structure, essential parts and image of shopping centers are elaborated upon. First of all, this leads to the heightened role of center's ability to provide a unique experience of making a purchase, as opposed to simply providing goods, in light of the rapid growth of ecommerce. Another important development is the trend towards mixed-use and social role of connective transit-recreational spaces of shopping complexes, accompanied by the requirement of greater awareness of local populace's needs and way of life. Last but not the least, an increased interest in shopping center's artistic image's authenticity is observed. Additional possibilities in that regard can be found in the use of methods of placemaking in creating the center's environment, as well as the involvement of regional cultural resources in its design.

Keywords: shopping mall, shopping center, sustainable development, public space, connective transit-recreational space, placemaking.

Introduction. A series of problems in the field of large shopping malls design has become apparent in 1990-2000s, being the most prominently present in USA markets. For a time, periodical publications spoke about the "death" of shopping mall as a 
building type and a retail agglomeration format. Although further developments have proved these conjectures to be premature, the amount of shopping centers of a traditional introverted structure that has lost tenants, declined or closed its doors, leads us to consider aforementioned problem and its causes with utmost attention. The influence of this problem and practical approaches directed towards its solution are also apparent in new shopping centres that are built around the world. Thus it is deemed practical to analyse the causes and consequences of the apparent shift of perspective that is observed in the practice of design and construction of large and, especially, urban shopping centres nowadays.

There exists a significant amount of literature dedicated to the aforementioned problem and its consequences. This article's theoretical base consists of a number of these sources that is considered to be illustrative of an issue and suitable for an analysis on the shift of perspective in shopping centre design. First of all, there are periodic publications that highlight the existence and relevance of a problem [1-4]. The history and peculiarities of USA experience in shopping mall design is presented in the first part of EPA guidebook for reorganization of commercial strip [5]. Meanwhile, an article by V. Raimers and V. Clulow [6] describes the problems in functionality and the loss of comfortability apparent in modern shopping malls with introverted structure. The changes in demands of modern customers are illustrated in reports and materials of ULI [7, 8]. The article by J. Stillerman and R. Salcedo [9] studies the relation of shopping center's visitors to its environment as a variation on an urban one, with said issue additionally highlighted in works of J. Goss [10], O. Berezko [11], M. Davidenko [12]. Additionally, R. Gratz [13] provides valuable information concerning the case of successful introduction of a shopping center designed with use of local cultural resources into an urban fabric of Boston. The regional peculiarities of shopping mall design are additionally touched upon in works of Zheng Tan [14], E. Danylenko [15], A. Borysenko [16] and others.
Materials and methods. Article materials are presented using the narrative method with results based on an analysis of recent publications in shopping center's theory with a series of examples illustrating modern trends and problems apparent in shopping centers today. The selection of examples is aimed to highlight important changes to shopping centers' structure and functioning as opposed to traditional model employed as universal throughout the world.

Results. The first evident cause for the need of change in shopping center design is the crisis of large shopping malls with traditional introverted structure (meaning they have a closed, inward facing strictly utilitarian structure with largely enclosed spaces). This crisis is most pronounced in USA, where the explosive growth and rapid evolution of shopping malls in 1950-1960s is connected with a series of local factors, such as the heavy urban decentralization and the taxation law of "accelerated depreciation" for commercial structures which subsidized its rapid construction. Subsequently, it led to the wrong evaluation of a number of shopping malls' construction sites as well as a general oversaturation of market in this building type [5]. Due to sharply increased competition and a lack of loyal customer base, a number of shopping malls in USA has closed its doors, turning into so called "dead" malls. However, general demographic and economic trends in the world allow us to expect similar outcomes in other countries' building markets. "South China Mall" in Dongguan can serve as a prominent example in this regard. Aimed to become the largest mall in China, instead it became the world's largest shopping mall that went vacant due to mistakes made in its program and geographic positioning [4].

Meanwhile, part of introverted shopping mall's problem appears to be systematic, born of its evolution in the chosen capacity of "machine of sales". The genesis and development of the shopping mall is connected with the provision of a protected enclosed environment with controlled microclimate to its visitors. The agglomeration of shops surrounding the safe pedestrian zone inside allowed to greatly minimize time losses for consumers. However, during the evolution of shopping 


\section{Cepia "APXITEKTYPA》}

mall's qualities this effect became compromised time and again in favour of increasing retention, the time that visitor spends on the center's premises, and his/her corresponding spendings. The competition among shopping malls and new formats of retail agglomerations are also regarded in context of time and effort loss minimization by its visitors. There, the most recent formats such as online shops, "lifestyle centers" and "category killers" have an edge over traditional malls. The visitors of shopping centers are divided in two groups - those who have a primarily utilitarian motivation for visit (namely, the need for purchase), and those who are driven by hedonistic motives (favouring the overall atmosphere and experience of shopping and accompanying activities). Visitors from a hedonistic group prefer the "lifestyle centers" (shopping centers with open spaces often resembling urban environment), while "utilitarian" visitors favour online shopping and "category killers" (large centers focusing on a certain type of merchandise), where they can make their purchases quickly and efficiently. Overall, the amount of male shoppers has shown to be increased; combined with the general lack of time that is characteristic of modern way of life, this leads to a greater number of customers that appreciate comfort as a way of saving their time and efforts. Another fact worth consideration is the generally increased age of customers, which, coupled with rising health problems, leads to the need for barrierless and comfortable environment. All in all, it has to be noted that the development of shopping mall's structure despite these trends has played a part in the decrease of its patronage by the group of "utilitarian" shoppers [6].

Another important factor is the change in customer base, namely, the introduction of "Generation Y" shoppers (aged from 23 to 40 years, as of 2018). The study of this visitor group's preferences has been conducted in USA [7], however the information present also describes the general interests and needs of representatives of modern information society that is rapidly changing. A significant part of the studied group perceives their visit to the shopping mall as a social activity and a form of entertainment. It has also been determined that the development of electronic commerce did not force this group of shoppers to stop visiting physical shopping premises, however, it did increase the demand for the integration of virtual and real space using modern digital technologies in shopping center's environment. A characteristic example of these factors influencing the decline of more traditional malls is the closing and subsequent demolishment of "Funan DigitaLife Mall" in Singapore. This mall specialised in electronics and was closed due to the change of preferences of its supposed customer base in the wake of the development of online shopping.

The change in shopping center design is illustrated in "Ten principles for rethinking the mall", a report by Urban Land Insitute (a non-profit organisation dedicated to research and education, based in USA) [8]. It presents ideas and proposes methods for the reorganisation and repositioning of shopping malls in light of recent challenges that this building type faces in modern world, as concerned with modern commerce and urbanisation processes. Report emphasizes an importance of shopping center's connection to the needs and desires of local community, proposing the employment of participation techniques to achieve it. It is also important to note the new interest towards an authenticity of shopping center's architectural environment as opposed to bleak standardized appearance that is associated with shopping malls now. This trend correlates with the growing preference towards open spaces resembling the more traditional urban fabric as well as the need for more diverse, accessible pedestrian spaces and the tighter integration of shopping experience into local population's everyday life. These patterns in addition to changes in customer's behaviour and growing competition between retail agglomeration types signal the need to re-evaluate an idea of shopping center's expected image and function.

Discussion. The aforementioned trends showcase the existence of a shift of perspective in shopping centre design, caused by the crisis of traditional introverted shopping malls, which leads to the branching of shopping center's typology and the search for interdisciplinary solutions (involving sociology 
and urban sciences). Speaking of building market's reaction to the apparent changes, the first and the most illustrative is the practice of construction of very large (usually, superregional) shopping malls with an increased part of entertainment functions - so called destination malls. Its increased catchment area is provided by the uniqueness of atmosphere and the range of proposition, while the rareness of visits due to increased range is compensated by an increase in time that visitors spend inside. Aside from concerns voiced in work by V. Raimers which appears to be particularly applicable to this solution, there simply is no place for a large number of such malls in its visitors' life routine. Additionally, its gargantuan size is an argument against its placement in an urban fabric. Among chief concerns in this regard are the overloading of urban infrastructure, deformation of pedestrian movement patterns, draining effect it will cause on existing traditional urban commercial spaces depriving it of its visitors, as well as a visual and morphologic incompatibility of characteristic large shopping mall's introverted architectural image and structure with its surrounding environment in the city.

The variants of "dead" malls' decayed spaces transformation are rather distinctive usually, they are being rebuilt into a more open pedestrian mixed-use environment, including commercial, entertainment, public and residential functions, in the spirit of "new urbanism". The focus in construction of superlarge enclosed shopping malls has moved from USA into China and the countries of South-Eastern Asia, where in light of rapid urbanisation processes nowadays the more traditional examples of this building type are being erected. However, an increased role of entertainment in shopping center's function is a more universal development. All in all, the most prominent among the recent trends in shopping center design are its focus on the experience being inside for visitors, the shift towards mixed-use and the greater openness of its structure, facilitating both psychological and physiological accessibility of its spaces and, correspondingly, the greater integration of shopping center into its environment.
One of the shopping center's type that enjoys a new interest from architects in light of recent trends is a lifestyle center. Although first lifestyle centers were built in 1980s, its open spaces resembling a somewhat idealized fragment of urban fabric are seen to be promising in light of a recently increased role of "experience" marketing. However, it is important to note an accompanying issue that has become apparent in discussions about the nature of public space in the interiors of modern shopping malls. While seeking to derive a perceived visual and psychological character (summed as atmosphere) from downtown urban spaces, shopping center's inner environment is still distinct from them in an important way, namely by the genetically evolved properties of its spaces. It is being designed as a whole entity in all its spatial and functional complexity, directed by a centralized management and artificially programmed to invoke certain customers' reactions as dictated by the marketing purposes. This allows for the creation of the more manageable, predictable and comfortable shopping environment, while at the same time deprives it of the inner complexity of meanings, purposes of visit and variants of use that evolved in urban fabric over time. This issue was touched upon in the research of J. Goss [10] and O. Berezko [11], both of which characterised a shopping mall's connective transit-recreational space as a limited public space and a reduced urban environment correspondingly.

Another possible solution for making shopping center a place that would invoke positive feelings of belonging and loyalty from its customers lies in the use of an urban environmental approach, or the placemaking. This approach largely analogizes shopping center's spaces with urban environment in its perception by visitors and consequently utilizes the similar arsenal of methods in working with both. In particular, it declares the lack of universal solutions suitable for all places. Shopping centers are supposed to correspond to the needs of local community, which includes the local context for the perceived environment and the available possibilities and regional peculiarities of public life. This links to the issue of "place" and 


\section{Cepia "APXITEKTYPA》}

"placelessness", as was discussed in broader context by Relph [17], and the integration of shopping complexes' environment into a local way of life. This also coincides with the research stating that people freely transpose their urban behavioural practices into the malls' spaces, perceiving it as a part of urban environments' continuity [9].

It is also important to note that the concept of sustainable development, having nowadays included the domain of culture, requires attention to the local cultural resources and potential. Among these resources as connected to shopping center design are the traditional perception codes describing forms and spaces, uses and meanings familiar to local population, the characteristic atmosphere, types and forms of activities peculiar to the region, as well as the existence of suitable structures and places with linked semantic narratives that can be utilized in shopping center's construction or the definition of its program. "Faneuil Hall Marketplace" in Boston and "Ghirardelli Square" in Los-Angeles can serve as examples of utilizing local cultural resources in its design, as both employed older structures and local semantic narratives in its program. Roberta Gratz denotes "Faneuil Hall Marketplace" as a successful example of large shopping conglomerate's integration into a historic urban environment, particularly because of the genetic connection between structure and the genetic function associated with the place [13]. Meanwhile "Ghirardelli Square", which is situated on the premises of old chocolate factory, also uses its historical buildings alongside new structures and incorporates the historic narrative of the place into its program, demonstrating another successful use of a placemaking approach.

All in all, modern trends in shopping center design emphasize the importance of several shopping centre's qualities, namely, the significance of its overall program (including narrative idea), the use of existing local resources (ranging from material to semantic ones), the mixed use of its spaces (allowing to synergistically enhance available activities and to provide the accompanying environment with more complex meaning) and the usage of participation methods, both in defining the type of future shopping center as well as during its subsequent existence. Therefore, the modern shopping center's structure is supposed to be dynamic, allowing a degree of flexibility to its composition and function with the goal of fine-tuning the tenant-mix and the logic of center's usage to the local population's needs and requests. An issue of choosing a semantic concept for the shopping center while utilizing local cultural resources is considered to be of particular interest to the goals of present research. Said resources' pool potentially includes the existing structures, which function can be changed without damaging their historical value within the framework of revitalization programs, the architectural references to the regionally distinct styles and approaches, the narratives of local significant places and objects with associated meanings, and so on. This development taken in the framework of sustainable development paradigm allows to bring additional arguments towards preserving regional peculiarities in culture while possibly mitigating the potential negative urban impact of shopping centers placed in urban fabric, therefore making the further study of mentioned regional resources and its application in the field of shopping center design a promising avenue of research.

\section{Conclusions}

1. The first and most prominent cause for the shift of perspective in shopping center design in 2000-2010s is the increased competition due to the oversaturation of shopping center's proposition in the world, which forced architects and developers to look for alternative ways of gaining advantage. In addition to that, architectural solutions taken in context of traditional utilitarian paradigm has often lead to a decrease in shopping center's comfortability to visitors, undermining a significant part of its initial appeal. Another important factor is the development of electronic commerce that has pulled over a sizable part of purchases connected with the convenience and the necessity. Furthermore, it brought to light an increased importance of another type of shopping, namely the shopping for experience - emphasizing the feelings and experience that accompany making a purchase, socializing and belonging to a 


\section{Cepia "APXITEKTYPA》}

place with a distinct character and atmosphere.

2. The social content of shopping center's visit, the activation of the communication possibilities and the distinct, unique atmosphere of its environment contribute to its success in the market of selling experience. Overall, this development leads to the greater role of mixed-use solutions and the public interpretation of its connective transit-recreational spaces likened to a reduced urban environment. In light of the modern concept of sustainable development (including, among others, the requirement of stable continuous cultural development), the need to utilize an existing regional potential is able to play a more prominent part than before. In light of the aforementioned potential, the possibilities of greater integration of the shopping center into an urban environment surrounding it include registering the regional architectural, cultural and social peculiarities, the way of life as well as the needs and expectations of local populace, with the goal of consequently reflecting it in center's structure and image.

3. The shopping malls, being objects of significant investments in its building stage, became factors of substantial commercial risk, especially apparent with an increased competition in light of continued construction of the new centers while the consumer base of population remains stable or even declines (as is evident in case of Ukraine). Therefore, it becomes important to seek the characteristic traits, peculiarities of atmosphere and market niches of use for new centers in the structure of customer's potential interests for every particular solution. It is important to note that while the shopping center's market in Ukraine has not yet reached saturation, as is the case in USA, the general trends in the design and use of this building type points toward the similar path of evolution, even if it is mostly adopted from world's examples. In addition to that, the rapid development of e-commerce may accelerate the appearance of crisis phenomena, because it is a factor that came earlier into play in Ukrainian market rather than in USA. Therefore, it is deemed important to take the new trends connected with the crisis of traditional shopping center's format and structure and its consequences for shopping center design into consideration.

\section{REFERENCES:}

1. Jonathan Glancey. The death of the US shopping mall. ВBC: веб-сайт URL: http://www.bbc.com/ culture/story/20140411-is-the-shopping-malldead (дата звернення: 14.04.2019).

2. David Uberti. The death of American mall. The Guardian: веб-сайт URL: https://www.theguardian.com/cities/2014/jun/19/-sp-death-of-theamerican-shopping-mall (дата звернення: 14.04.2019).

3. Tim Denman, Jamie Grill-Goodman. The Death of the Mall as We Know It. Retail Info Systems (RIS) News: веб-сайт URL: https://risnews. com/death-mall-we-know-it (дата звернення: 28.03.2019).

4. Данилов С.М. Инновационная архитектура проблемы и достижения (часть первая - проблемы). Науковий вісник будівниитвва. 2017. T. 89. № 3. C. 38-46.

5. Restructuring the Commercial Strip: A Practical Guide for Planning the Revitalization of Deteriorating Strip Corridors. ICF International (Firm), Freedman Tung \& Sasaki, United States Environmental Protection Agency: веб-сайт URL: https://nacto.org/wp-content/uploads/2015/04/

Reconstructing-the-commercial-strip_ICFinternational.pdf (дата звернення: 14.04.2019).

6. Vaughan Raimers, Valerie Clulow. The role of convenience in the evolution of the mall. ANZMAC. 9 p. 2009. URL: http://www.dup-lication.net.au/ANZMAC09/papers/ANZMAC2009-408.pdf (дата звернення: 14.04.2019).

7. Leanne Lachman M., Deborah L. Brett. Generation Y: Shopping and En-tertainment in a Digital Age. // Washington, D.C. Urban Land Institute. 2013. URL: http://uli.org/wp-content/uploads/ ULI-Documents/Generation-Y-Shopping-andEntertainment-in-the-Digital-Age.pdf (дата звернення: 14.04.2019).

8. Michael D. Beyard, Mary Beth Corrigan, Anita Kramer, Michael Pawlukiewicz, Alexa Bach. Ten principles for rethinking the mall. Washington, D.C.: Urban Land Institute. 2006. URL: http://uli.org/wp-content/uploads/ULI-Documents/Tp_MAll.ashx_.pdf (дата звернення: 14.04.2019).

9. Joel Stillerman, Rodrigo Salcedo. Transposing the Urban to the Mall: Routes, Relationships, and Resistance in Two Santiago, Chile, Shopping Centers, 41(3), pp. 309-336. 2012. URL: http://jce.sagepub.com/content/41/3/309.full.pdf (дата звернення: 14.04.2019).

10. Goss J. The "Magic of the Mall": An Analysis of Form, Function, and Meaning in the Contemporary Retail Built Enviroment. Annals of the Association of American Geographers. 1993. Vol. 83, № 1. P. 18-47. 


\section{Cepia "APXITEKTYPA》}

11. Березко О.В. Архітектурно-планувальна організація комунікативного простору у структурі торгово-розважальних центрів: дис. ... канд. арх.: 18.00.02. / Львів, 2017. 225с.

12. Давиденко М. Молл и город: хроники поединка титанов. АССбуд - строительный портал. веб-сайт URL: http://www.accbud.ua/ architecture/tekstura/moll-i-gorod--khronikipoedinka-titanov-chast-1. (дата звернення: 14.04.2019 p.).

13. Грац Р. Город в Америке: жители и власти. / Пер. $з$ англ. В.Л. Глазичева. М.: Ладья, 1995. $416 \mathrm{c}$.

14. Zheng Tan. Townscape in a High-rise: Imageability and Accessibility of Vertical Malls in Hong Kong. International Journal of High-Rise Buildings. 2015. Vol. 4, № 2. P. 143-152.

15. Даниленко Є.Л. Принципи формування суспільно-торгівельних просторів у житловій забудові міста: автореф. дис. ... канд. арх.: 18.00.01. / ХНУБА, Харків, 2010. 20c.

16. Борисенко A.C. Regionalistic approach to shopping malls' integration into urban environment the premises and possibilities. Науковий вісник будівниитва. 2018. Т. 92, № 2. С. 5-11.

17. Edward Relph. Place and placelessness. Pion Ltd; UK ed. Edition, 2008. 174p.

Смоленська С.А., Борисенко А.С. ЗМІНА ПЕР-
СПЕКТИВИ В ДИЗАЙНІ ТОРГОВИХ ЦЕНТ-
РІВ 2000-2010рр. СтатТю присвячено досліPIB 2000-2010pp. Статтю присвячено дослі-
дженню сучасних тенденцій в проектуванні нових торгівельних центрів у світі. 3 цією метою був проведений аналіз сучасних публікацій, присвячених теорії даного типу споруд, а також найбільш помітних прикладів змін у проектуванні та функціонуванні торгівельних центрів у 2000-2010-і рр. На базі цього було висунуто припущення стосовно основних причин наміченого зсуву у поглядах на проектування, а також наслідків для структури, наповнення та образу торгівельних центрів, яким віддається перевага в світлі нових підходів. Перш за все, це підвищена роль надання унікального досвіду закупівлі на противагу одній наявності товару, пов'язаного з нею, нагальна необхідність інтеграції цифрових технологій до функціонування фізичних просторів торгівельного центру, тенденція до «змішаного використання» та громадського прочитання рекреаційно-комунікаційних просторів комплексу, більша увага до способу життя та потреб місцевого населення, а також нова зацікавленість в автентичності художнього образу торгівельного центру на противагу до невиразного, стандартизованого вигляду, що став асоціюватися 3 цим типом споруд. Додатковими можливостями в цьому відношенні слугують використання заходів середовищного підходу у проектування середовища торгівельного центру, подібного до редукованого міського середовища, і задіяння регіональних культурних ресурсів.

Ключові слова: торгівельний центр, сталий розвиток, громадський простір, рекреаційно-комунікаційний простір, середовищний підхід.

Смоленская С.А., Борисенко А.С. ИЗМЕНЕНИЕ ПЕРСПЕКТИВЫ В ДИЗАЙНЕ ТОРГОВЫХ ЦЕНТРОВ 2000-2010гг. Статья посвящена изучению современных тенденций в проектировании новых торговых центров в мире. С этой целью был проведен анализ современных публикаций, посвященных теории данного типа сооружений, а также наиболее заметных свидетельств изменений в проектировании и функционировании торговых центров в 2000-2010-е гг. На базе этого были выдвинуты предположения о основных причинах наметившегося сдвига во взглядах на проектирование, а также о последствиях для структуры, наполнения и образа торговых центров, которым отдается предпочтение в свете новых подходов. Прежде всего, это повышенная роль предоставления уникального опыта, сопровождающего покупку, в противовес одному лишь наличию товара, с ней связанного, насущная необходимость интеграции цифровых технологий в функционирование физических пространств торгового центра, тенденция к «смешанному использованию» и общественному прочтению рекреационно-коммуникационных пространств комплекса, большее внимание к образу жизни и потребностям местного населения, а также новый интерес к аутентичности художественного образа торговых центров в противовес невыразительному стандартизированному виду, что стал ассоциироваться с ними. Дополнительными возможностями в этом отношении служат использование средств средового подхода в проектировании среды торгового центра, подобной редуцированной городской среде, и задействование региональных культурных ресурсов.

Ключевые слова: торговый центр, устойчивое развитие, общественное пространство, рекреационно-коммуникационное пространство, средовой подход. 